\title{
Effects of pentagastrin and IGF-1 on DNA synthesis of rumen epithelial cells of dairy cow and neonatal calf*
}

\author{
Z. Shen ${ }^{1}$, Y. Su, J. Chen and W. Chen \\ Lab of Animal Physiology and Biochemistry, Nanjing Agricultural University \\ Weigang, Nanjing 210095, China
}

\begin{abstract}
Pentagastrin (PG) $\left(10^{-12}, 10^{-11}, 10^{-10}\right.$ and $\left.10^{-9} \mathrm{~mol} / \mathrm{L}\right)$ and IGF-1 $(25$ and $50 \mu \mathrm{g} / \mathrm{L})$ increased DNA synthesis of rumen epithelial cell (REC) of dairy cows in a dose dependent manner by approximately $30-40 \%$ and $13 \%(\mathrm{P}<0.05)$, respectively. Proglumide (gastrin/CCK B receptor blocker) abolished the trophic action of $\mathrm{PG}$, which indicates that the positive effect of $\mathrm{PG}$ on REC is probably mediated by the gastrin receptor. REC of neonatal calves did not response to PG. However, IGF-1, at all given doses $(25-200 \mu \mathrm{g} / \mathrm{L})$, promoted DNA synthesis in REC of neonatal calves $(\mathrm{P}<0.05)$.
\end{abstract}

KEY WORDS: pentagastrin, IGF-1, rumen epithelial cells, dairy cow, neonatal calves

\section{INTRODUCTION}

Gastrin and insulin-like growth factor-1 (IGF-1) exert cell-proliferative effects on rumen epithelial cells (Baldwin, 1999). Gastrin, mediated by receptor, promotes hyperplasia of epithelia in the digestive tracts of man, pig and rodent. Despite its high concentration in plasma, gastrin has very weak effects on neonatal gastrointestinal growth, due to the postnatal development of its receptor (Dufresne et al., 1999). IGF-1 concentration is high and IGF type 1 receptor (IGF1R) was detected in duodenum, jejunum, ileum, and colon of newborn calves. We hypothesized that IGF-1 rather than gastrin stimulates rumen development in neonatal calves. This paper describes proliferative responses of REC of dairy cows and neonatal calves to gastrin and IGF-1.

\footnotetext{
* Supported by Chinese Nature Science Fundation, No. 39970552, 30270972

${ }^{1}$ Corresponding author: e-mail: zmshen@njau.edu.cn
} 


\section{MATERIAL AND METHODS}

Rumen papillae from the ventral blind sac of multiparous dry cows $(\mathrm{n}=12)$ and neonatal calves $(\mathrm{n}=7,1 \mathrm{~d}$ old), collected from local slaughterhouse, were digested by trypsin $(0.25 \%)$ at $37^{\circ} \mathrm{C}$ to gain dissociated cells. Individual rumen epithelial cell were resuspended in culture medium (MEM, Gibco), adjusted to $10^{9-10} / \mathrm{L}$, seeded to a 24 -well plate $(1 \mathrm{ml} /$ well $)$ and incubated at $37^{\circ} \mathrm{C}$ with $5 \% \mathrm{CO}_{2}$ for 24 $\mathrm{h}$ to allow attachment. After attachment, 1 . the PG at concentrations of $0,10^{-12}$, $10^{-11}, 10^{-10}, 10^{-9}$ and $10^{-8} \mathrm{~mol} / \mathrm{L}$ and $\mathrm{LR}_{3}-\mathrm{IGF}-1$ (Sigma, USA), an analog of IGF-1, which stimulated DNA synthesis of rumen epithelial cell of young goats in vitro effectively (Shen et al., 2004) at $0,25,50,100$ and $200 \mu \mathrm{g} / \mathrm{L}$ was administrated to the cultured REC of cows ( $\mathrm{n}=3$ and $n=4)$ for $10 \mathrm{~h}$, respectively. 2. Proglumide $\left(10^{-8} \mathrm{~mol} / \mathrm{L}\right)$, a blocker of gastrin/CCK B receptor, was simultaneously added with PG to REC of cow ( $n=5)$. 3. REC of calves $(n=7)$ was exposed to PG and IGF-1, respectively. DNA synthesis was measured by incorporation of ${ }^{3} \mathrm{H}-\mathrm{TdR}(1 \mathrm{Ci} / \mathrm{ml})$ into cell DNA, and radioactivity was expressed as disintegrations per minute (dpm) or per second (dps).

The data are expressed as mean \pm SEM. Differences were analysed by T test with $\mathrm{P}<0.05$ considered as significant.

\section{RESULTS}

DNA synthesis of REC of cows ( $\mathrm{n}=3$; Figure 1) increased in a dose-dependent manner by approximately $30-40 \%(\mathrm{P}<0.05$ and $\mathrm{P}<0.01)$ in response to $\mathrm{PG}\left(10^{-12}-10^{-10}\right.$ $\mathrm{mol} / \mathrm{L})$. Proglumide abolished the trophic action of $\mathrm{PG}(\mathrm{P}<0.05)$, when REC of cow $(\mathrm{n}=5)$ was exposed simultaneously to $\mathrm{PG}\left(10^{-12} \mathrm{~mol} / \mathrm{L}\right)$ and proglumide $\left(10^{-8} \mathrm{~mol} / \mathrm{L}\right)$ (Figure 2). IGF-1 ( 25 and $50 \mu \mathrm{g} / \mathrm{L})$ stimulated DNA synthesis of REC of cows $(\mathrm{n}=4$, $\mathrm{P}<0.05)$. In neonatal calves ( $\mathrm{n}=7)$ IGF-1 $(25,100$ and $200 \mu \mathrm{g} / \mathrm{L})$ significantly increased DNA synthesis at all concentration by about $25 \%, 70 \%$ and $50 \%$, respectively (Table 1). However, PG did not change DNA synthesis (Table 2) of neonatal calves ( $\mathrm{n}=7)$.

Table 1 . IGF-1 on DNA synthesis (DPS) of REC in dairy cows $(n=4)$ and calves $(n=7)$

\begin{tabular}{lccccc}
\hline IGF-1, $\mu \mathrm{g} / \mathrm{L}$ & 0 & 25 & 50 & 100 & 200 \\
\hline Cows & $12672 \pm 685$ & $14553 \pm 339^{*}$ & $14353 \pm 345^{*}$ & $14286 \pm 1319^{1}$ & $12005 \pm 1133$ \\
Calves & $26611 \pm 6702$ & $33668 \pm 6252^{* *}$ & & $45265 \pm 6415^{*}$ & $40759 \pm 6515^{* *}$ \\
\hline
\end{tabular}

${ }^{*}$ - $\mathrm{P}<0.05,{ }^{1}-0.05<\mathrm{P}<0.16,{ }^{*} *_{-} \mathrm{P}<0.01$, dps - radioactivity disintegrations per sec

Table 2. Pentagastrin on DNA synthesis (DPS) of REC in neonatal calves $(n=7)$

\begin{tabular}{lcccc}
\hline Pentagastrin, $\mathrm{mol} / \mathrm{L}$ & 0 & $10(-11) \mathrm{mol} / \mathrm{L}$ & $10(-10) \mathrm{mol} / \mathrm{L}$ & $10(-9) \mathrm{mol} / \mathrm{L}$ \\
\hline Calves & $26611 \pm 6700$ & $25345 \pm 4455$ & $24294 \pm 3393$ & $26765 \pm 5528$ \\
\hline
\end{tabular}

dps - radioactivity disintegrations per second 


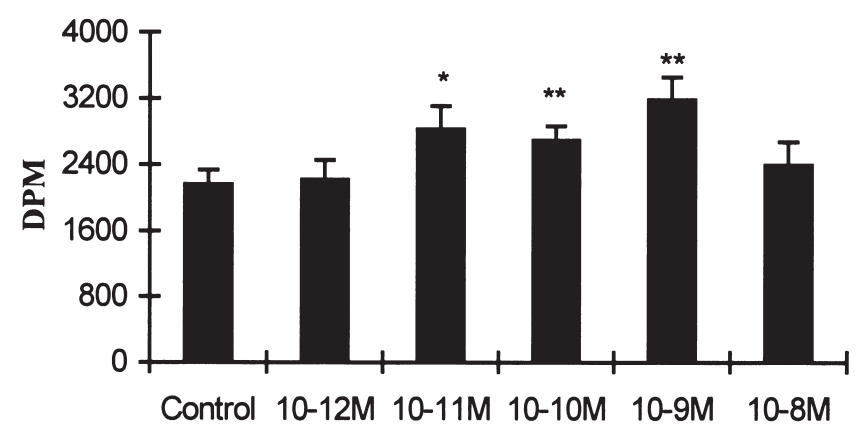

Figure 1. Pentagastrin on DNA synthesis of REC in dairy cows. ${ }^{*} \mathrm{P}<0.05$; ** $\mathrm{P}<0.01$; DPMdisintegrations per $\min$

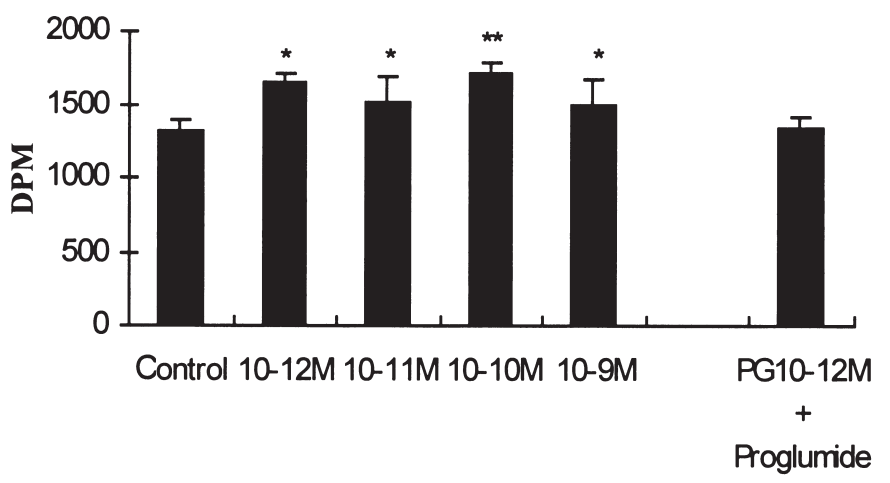

Figure 2. Proglumide on trophic action of pentagastrin. * $\mathrm{P}<0.05$; ** $\mathrm{P}<0.01$; DPM - disintegrations per min

\section{DISCUSSION}

The stimulating effect of PG on DNA synthesis of REC in cow was consistent with others. Moreover, our data demonstrated that this trophic effect of gastrin, abolished by gastrin/CCK B blocker (proglumide), was mediated by its receptor. PG did not change DNA synthesis in REC of neonatal calves, which can be explained by the previous finding of the postnatal development of the gastrin receptor (Dufresne et al., 1999). IGF-1 and IGF-1R mRNA was detected in rumen papillae, and nutritional up-regulating of papillae size was associated with increased IGF-1 concentration in peripheral blood plasma and more IGF$1 \mathrm{R}$ in rumen papillae, indicating that IGF-1 promotes ruminal cell growth via IGF-1R (Shen et al., 2004). Furthermore, functional GH, IGF-1, IGF-2, IGF-1R and binding proteins are found in neonatal gastrointestinal mucosa. Possibly, somatotropic axis is a basic regulator of postnatal rumen development in the suckling calves. 


\section{CONCLUSIONS}

Both gastrin and IGF-1 stimulate rumen epithelial cell proliferation of adult cattle, via their receptors. In the postnatal period the trophic action of gastrin on rumen development was preceded by IGF-1, resulted from a programmed agedependent maturity of IGF-1 and gastrin receptors in rumen epithelium.

\section{REFERENCES}

Baldwin R.L., 1999. The proliferative actions of insulin, insulin-like growth factor-1, epidermal growth factor, butyrate and propionate on ruminal epithelial cells in vitro. Small Ruminant Res. 32, 261-268

Dufresne M., Escrieut C., Clerc P., Le Huerou-Luron I., Prats H., Bertrand V., Le Meuth V., Guilloteau P., Vaysse N., Fourmy D., 1999. Molecular cloning, developmental expression and pharmacological characterization of the $\mathrm{CCKB} /$ gastrin receptor in the calf pancreas. Eur. J. Pharmacol. 297, 165-179

Shen Z., Seyfert H.M., Lohrke B., Schneider F., Zitnan R., Chudy A., Kuhla S., Hammon H.M., Blum J.W., Martens H., Hagemeister H., Voigt J., 2004. An energy-rich diet causes rumen papillae proliferation associated with more IGF type 1 receptors and increased plasma IGF-1 concentrations in young goats. J. Nutr. 134, 11-17 